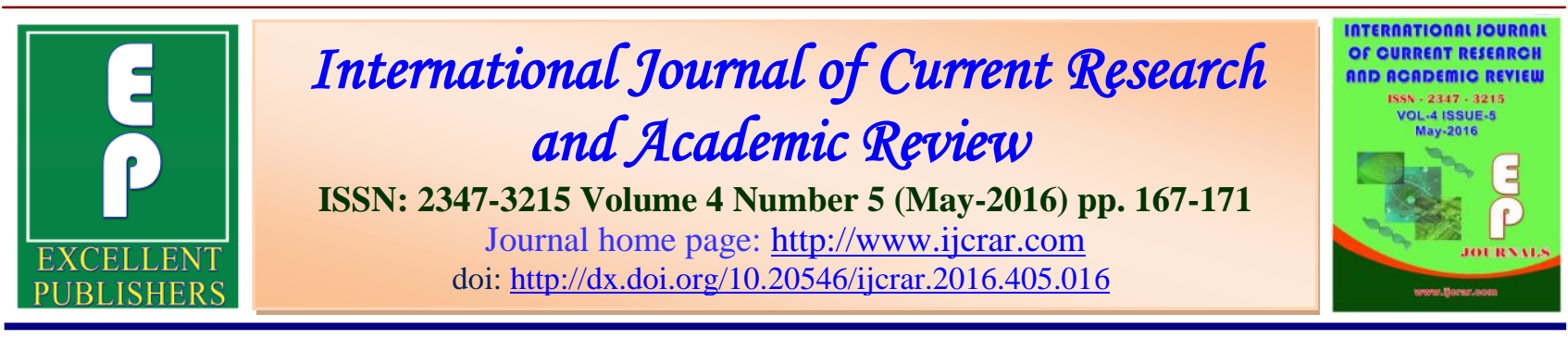

\title{
A Study of Phytotoxicity and Decolorization of Methyl Orange Dye by Bacillus Sp.
}

\author{
Ramesh S. Masarbo*
}

Assistant Professor, Department of Chemistry, A V Patil Degree College of Arts, Science \& Commerce, Aland, Gulbarga, Karnataka, India

*Corresponding author

\begin{tabular}{|l|l|}
\hline \multirow{2}{*}{$\begin{array}{l}\text { KEY } \begin{array}{l}\text { Azo dyes, } \\
\text { Decolorization, } \\
\text { Phytotoxicity, }\end{array} \\
\begin{array}{l}\text { NaCl, } \\
\text { Textile dye. }\end{array}\end{array}$} & $\begin{array}{l}\text { Azo dyes accounts for the majority of all textile dyestuffs produced and have } \\
\text { been most commonly used synthetic dyes in the textile, paper and leather } \\
\text { industries. Methyl Orange is one such azo dye, which is widely used in } \\
\text { textile industries and also as an indicator in chemical laboratories. In the } \\
\text { present study effect of } \mathrm{NaCl} \text { salt concentration, effect of presence or absence } \\
\text { of nitrogen source and phytotoxicityof Methyl orange and its degradation } \\
\text { products is studied. Presence of } 5 \mathrm{~g} / \mathrm{l} \text { of } \mathrm{NaCl} \text { did had any negative impact on } \\
\text { decolorization efficiency. There was slight delay in time taken for } \\
\text { decolorization at and above } 20 \mathrm{~g} / \mathrm{l} \text { of NaCl in the media. Optimum amount of } \\
\text { peptone for the efficient decolorization was found to be } 5 \mathrm{~g} / \mathrm{l} \text {. Presence of less } \\
\text { than or more than } 5 \mathrm{~g} / \mathrm{l} \text { of peptone has delayed the decolorization time and } \\
\text { reduced the decolorization efficiency. }\end{array}$ \\
\hline
\end{tabular}

\section{Introduction}

Approximately 10,000 different dyes and pigments are used industrially and over 0.7 million tonnes of synthetic dyes are produced annually worldwide (Palmeiri, 2005). During processing upto $15 \%$ of the used dyestuffs is lost in the industrial effluents. Azo dyes accounts for the majority of all textile dyestuffs produced and have been most commonly used synthetic dyes in the textile, paper and leather industries. Methyl Orange is one such azo dye, which is widely used in textile industries and also as an indicator in chemical laboratories. In addition to their visual effects and their adverse impact in terms of Chemical oxygen demand, many synthetic azo dyes show their toxic, carcinogenic and genotoxic effects. Thus the textile wastewater containing Methyl Orange must be treated before release into the natural environment. These dyes have stable chemical structures and hence cannot be removed by conventional physical and chemical methods. In addition physicochemical methods are expensive, time consuming, ineffective and non ecofriendly (Eichlerova et al., 2006). On the 
other hand biological method has become one of the more favorable method due to their cost effective, environmental friendly lower sludge production compared to the physicochemical method (Mohana et al., 2008). It is worth noting that, fungi and bacteria are widely used for the degradation of textile dyes (Amar et al., 2010). Bacterial degradation of azo dyes is more advantageous as bacterial cell grow fast and their decolorization rate is also very high.

The focus of the present study was the study of effect of $\mathrm{NaCl}$ salt and peptone concentration on the efficiency of decolorization of Methyl orange dye by bacterium Bacillus sp. Strain and also phytotoxicity of Methyl orange and its degradation products was studied.

\section{Materials and Methods}

\section{Bacterial Culture}

Bacillus sp. Strain was previously isolated from dye contaminated soil sample collected around the Dyeing Industries, Solapur, India. This strain was capable of decolorizing azo dyes efficiently. This strain was grown under static condition at room temperature in Luria-Bertani (LB) broth.

\section{Dyes and Media}

The azo dye Methyl Orange was procured from sd fine chemicals ltd. Dye was checked for its color, solubility in water and absorption maximum. The mineral salt medium was prepared with following composition (g/l): $\mathrm{K}_{2} \mathrm{HPO}_{4}$ (6.3), $\mathrm{KH}_{2} \mathrm{PO}_{4}$ (1.8), $\mathrm{NaCl}$ (5), $\mathrm{NH}_{4} \mathrm{NO}_{3}$ (1), $\mathrm{MgSO}_{4} .7 \mathrm{H}_{2} \mathrm{O}$ (0.1), $\quad \mathrm{MnSO}_{4} \quad(0.1), \quad \mathrm{CaCl}_{2} .2 \mathrm{H}_{2} \mathrm{O} \quad(0.1)$, $\mathrm{FeSO}_{4} .7 \mathrm{H}_{2} \mathrm{O} \quad(0.1), \quad \mathrm{NaMoO}_{7} . \quad 7 \mathrm{H}_{2} \mathrm{O}$ (0.006). The final $\mathrm{pH}$ of the medium was adjusted to 7.2. The mineral salt medium was supplemented with yeast extract
$(2.5 \mathrm{~g} / \mathrm{l})$, peptone $(5 \mathrm{~g} / \mathrm{l})$ and Methyl orange dye $(200 \mathrm{mg} / \mathrm{l})$. All the chemicals used in this study were of analytical grade.

\section{Decolorization Experiments}

The decolorization experiments were performed in $250 \mathrm{ml}$ Erlenmeyer flasks containing medium. Methyl Orange $(200 \mathrm{mg} / \mathrm{l})$ was added to decolorization medium and inoculated with $2 \mathrm{ml}$ of cultures broth. The flasks were incubated at $40^{\circ} \mathrm{c}$ under static conditions till the decolorization was completed.

\section{Analytical methods for dye decolorization studies}

The samples were withdrawn at different time intervals and analyzed for decolorization efficiency. Decolorization was quantitatively analyzed by measuring the absorbance of the supernatant using a UV-Visible spectrophotometer at maximum wavelength. $\lambda_{\max }$ for Methyl Orange was $465 \mathrm{~nm}$. Decolorization percentage was calculated by using the equation

$\%$ Decolorization

$$
=\frac{\text { Initial absorbance-Final absorbance }}{\text { Initial absorbance }} \times 100
$$

\section{Study of Physico-chemical parameters}

Decolorization ability of strain on Methyl Orange was studied at different $\mathrm{pH}$ (5-9), temperature values $\left(15-50^{\circ} \mathrm{C}\right)$, dye concentration $(200-1000 \mathrm{mg} / \mathrm{l})$ etc. The effect of these physicochemical factors was studied.

It was observed that $\mathrm{pH} 7.2$ and temperature $37^{\circ} \mathrm{c}$ were found to be optimal for the decolorization activity. Effect of other factors was studied at $\mathrm{pH} 7.2$ and temperature $37^{\circ} \mathrm{C}$. 


\section{Phytotoxicity Studies}

The tests were carried out on Pigeon pea (Cajanus cajan) seeds commonly used in agriculture. The required concentration of Methyl orange showing inhibitory effect on the growth of seeds was selected for the study.

Ten seeds were germinated on a bedded filter paper with daily watering of $10.0 \mathrm{ml}$ solutions for respective samples. Simultaneously, a control set with the plain water was carried out.

The toxicity was measured in terms of percent germination and lengths of plumule and radical after 10 days. Relative seed germination, relative root elongation and germination index (GI) were calculated by the following formulae.

Relative Seed Germination (\%)

$$
=\frac{\text { No.of seedsgerminatedinextract }}{\text { No.of seedsgerminatedincontroldye }} \times 100
$$

Relative root elongation (\%)

$$
=\frac{\text { Meanrootelongationinextract }}{\text { Meanrootelongationincontroldye }} \times 100
$$

Germination Index (\%)

$$
=
$$

$(\%$ Seedgermination $) \times(\%$ Rootelongation $)$ 100

\section{Results and Discussion}

\section{Effect of $\mathrm{NaCl}$ Concentration}

Dye waste waters from both the dye manufacturing and dye consuming industries contain high salt concentration which is up to $15-20 \%$.

The effect of $\mathrm{NaCl}$ concentration on the decolorization of Methyl orange by the selected strain was examined. Decolorization efficiency was not affected at $\mathrm{NaCl}$ concentrations of $5 \mathrm{~g} / \mathrm{l}$ and $10 \mathrm{~g} / \mathrm{l}$. At $15 \mathrm{~g} / \mathrm{l}$ and $20 \mathrm{~g} / \mathrm{l} \mathrm{NaCl}$ concentrations the decolorization dropped to $75 \%$ and $64 \%$ respectively. Further increase in concentration of $\mathrm{NaCl}$ resulted in decreased percentage decolorization.

\section{Effect of Nitrogen Source}

The percentage decolorization increased with increase in peptone concentration up to $5 \mathrm{~g} / \mathrm{l}$ and after which there is decrease in percentage of decolorization.

The decrease in decolorization results from nitrate or nitrite, a reducing equivalent that cells generated from peptone consumption. These metabolites of nitrate or nitrite may compete with the azo dye and result in less decolorization.

\section{Phytotoxicity}

Phytotoxicity of Methyl orange and acidic and neutral fractions of ethyl acetate extracts of the cultures grown spent medium was investigated. There was a significant change in the lengths of plumule and radical of the seeds of pigeon pea in the water, control dye (Methyl orange) and degradation products of the treated samples.

The phytotoxicity results also suggested that the degradation products of Methyl orange were much less toxic to the seeds of pigeon pea. 


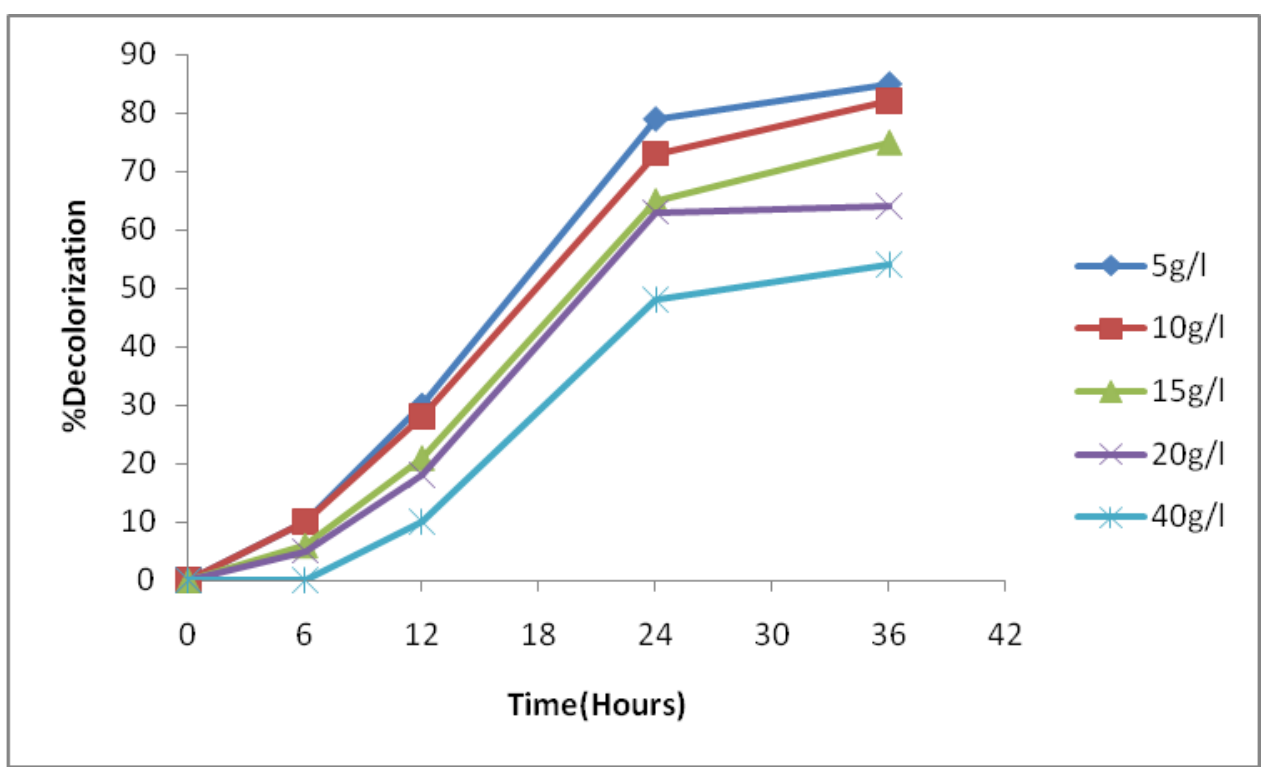

Figure.1 Effect of $\mathrm{NaCl}$ concentration on decolorization of Methyl orange

Table.1 Phytotoxicity of Methyl Orange and its degradation products on Pigeon pea.

\begin{tabular}{|l|l|l|l|l|}
\hline Parameter & Plain water & Pigeon pea & \multicolumn{2}{|l|}{ Degradation products } \\
\cline { 4 - 5 } & & & Acidic & Neutral \\
\hline Germination $(\%)$ & 100 & 68 & 75 & 78 \\
\hline Plumule $(\mathrm{cm})$ & $12.60 \pm 0.25$ & $4.2 \pm 0.16$ & $9.34 \pm 0.32$ & $10.87 \pm 0.43$ \\
\hline Radical $(\mathrm{cm})$ & $11.90 \pm 0.34$ & $4.5 \pm 0.23$ & $9.85 \pm 0.27$ & $10.46 \pm 0.36$ \\
\hline
\end{tabular}

\section{Conclusion}

Bacterial decolorization proves to be a very efficient method for complete decolorization of Methyl Orange. The purpose of this study is to investigate the decolorization of Methyl Orange by Bacillus sp. Strain. The bacteria successfully decolorize Methyl orange. Most markedly the strain could effectively decolorize the dye, Methyl orange over dye concentrations of $200-800 \mathrm{mg} / \mathrm{l}, \mathrm{pH}$ of $5-9$ and temperature $20-50^{\circ} \mathrm{c}$. Decolorization with Bacillus sp. yields high maximum decolorization activity of $85 \%$ at dye concentration 200mg/l, $\mathrm{pH} \quad 7$ and temperature $37^{\circ} \mathrm{c}$. It can be concluded that Bacillus sp. is highly promising and suitable microorganism for use in the treatment of textile waste water.

\section{Acknowledgements}

The author is highly grateful to UGC for the financial support under the scheme of Minor Research Project. Also thankful to Gulbarga University, Gulbarga and Principal and management of HKES's A. V. Patil College, Aland for providing the infrastructure facility for the research work.

\section{References}

Amar, A.T., Avinash, A.K., Sujit, S.J., Jyoti, P.J., Sanjay, P.G. 2010. Biochemical characterization and potential for textile dye degradation of blue laccase from Aspergillus ochraceus NCIM1146. Biotechnol. Bioprocess Engi, 15: 696-703. 
Chang, J.S., Chen, B.Y., Lin, Y.S. 2004. Stimulation of Bacterial decolorization of Azo dyes by extracellular metabolites of E. Coli Strain No.3., Bioresour. Technol., 91: 243-248.

Correia, V.M., Stephenson, T., Judd, S.J. 1994. Characterization of textile wastewaters - A review, Environ. Technol., 15: 917-929.

Dave, S.R., Dave, R.H. 2009. Isolation and characterization of Bacillus thuringiensis for Acid Red-119 dye decolorization. 100: 249-253

Eichlerova, L., Homolka, L., Nerud, F. 2006. Synthetic dye decolorization capacity of white rot fungus Dichomotus squalens. Biores. Technol., 97: 2153-2159.

Gupta, V.K., Mittal, A., Krishnan, L., Gajbe, V. 2004. Adsorption kinetics and column operations for the removal and recovery of malachite green from wastewater using ash. Separation and Purification Technol., 40: 87-96.

Mohana, S., Srivastava, S., Divecha, J., Madamwar, D. 2008. Response surface methodology for optimization of medium for decolorization of textile dye Direct Black 22 by a novel bacterial consortium. Biores. Technol., 99: 562-569.
Palmieri, G., Cennamo, G., Sannia, G. 2005. Remazol Brilliant blue $\mathrm{R}$ decolorization by the fungus Pleurotusostreatus and its oxidative enzymatic system. Enzyme and Microbial technol., 36: 17-24.

Pandey, A., Singh, P., Iyengar, L. 2007. Bacterial decolorization and degradation of azo dyes. Int. Biodeterior. Biodegrad., 59: 73-84.

Patil, P.S., Shebdalkar, U.U., Kalyani, D.C., Jadhav, J.P. 2008. Biodegradation of Reactive Blue 59 by isolated bacterial consortium PMB11, J. Ind. Microbiol. Biotechnol., 35: 1181-1190.

Stolz, A. 2001. Basic and applied aspects in the microbial degradation of azo dyes. Appl. Microbiol. Biotechnol., 56: 6980.

Sukumar, M., Sivasamy, A., Swaminathan, G. 2007. Decolorization of textile dye effluent by genetically improved bacterial strains, Appl. Biochem. Biotechnol., 136: 53-61.

Wang, S., Kong, J., Gao, C., Guo, T., Liu, X. 2010. Isolation and characterization of a novel phage of Lactobacillus delbruckii, Int. J. Food Microbiol., 137: 22-27.

\section{How to cite this article:}

Ramesh S. Masarbo. 2016. A Study of Phytotoxicity and Decolorization of Methyl Orange Dye by Bacillus Sp. Int.J.Curr.Res.Aca.Rev.4(5): 167-171. doi: http://dx.doi.org/10.20546/ijcrar.2016.405.016 